\title{
Investigation of Average Values of Prolidase, Adenozin Deaminase, Glutathione S-Transferase and Glutathione Reductase Enzymes in Pancreas Cancers
}

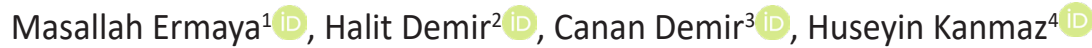 \\ ${ }^{1}$ Van Regional Training and Research Hospital, Van,Turkey. \\ ${ }^{2}$ Van Yuzuncu YIl University, Faculty of Science, Department of Biochemistry, Van,Turkey. \\ ${ }^{3}$ Van Yuzuncu Yil University, Vocational School of Health Care, Van, Turkey. \\ ${ }^{4}$ Van Regional Training and Research Hospital, Oncology Clinic, Van, Turkey. \\ Correspondence Author: Maşallah Ermaya \\ E-mail: masallahermaya65@gmail.com \\ Received: 18.01.2021 Accepted: 03.05.2021
}

\begin{abstract}
Objective: The purpose of this study is to determine the relationship between enzymatic antioxidants such as glutathione reductase and glutathione s-transferase and prolidase and adenosine deaminase in patients diagnosed with pancreatic cancer.

Methods: Prolidase, adenosine deaminase, glutathione s-transferase and glutathione reductase activities were determined spectrophotometrically in blood sera collected from patients and healthy control subjects included in the study.

Results: In patients with pancreatic cancer, the mean value of glutathione reductase and glutathione s-transferase enzymes decreased, while the mean value of prolidase, and adenosine deaminase, enzyme activities increased $(p<0.05)$.

Conclusion: In this study, in which prolidase, enzyme activity was first measured in pancreatic cancer, high prolidase, activity can be evaluated as a factor that increases the risk of cancer. Prolidase, adenosine deaminase, glutathione reductase and glutathione s-transferase enzyme activities may play an important role in the etiopathogenesis of pancreatic cancer.

Keywords: Adenosine deaminase, cancer, glutathione reductase, glutathione s-transferase, pancreatic cancer
\end{abstract}

\section{INTRODUCTION}

In cancer deaths, pancreatic cancer is in 4th place after lung, colorectal and breast cancer. Ductal adenocarcinoma accounts for approximately $85-90 \%$ of pancreatic cancers(1). Pancreatic adenocarcinoma is approximately 1.5 times more common in men than in women (2). The incidence of pancreatic cancer is increasing gradually in all developing countries (3). Especially of this rise is thought to be changes in diet and environmental factors in western societies. These causes make pancreatic cancer an important health problem (4). Diagnosis of pancreatic cancer; laboratory examinations and imaging methods and by pathological examinations are determined. The most important problem in diagnosis: none of the diagnostic methods cannot be detect cases smaller than $2 \mathrm{~cm}$ with high sensitivity and specificity. Most of the pancreatic carcinomas are seen in the head of the organ $(73.2 \%)$ and the other part is in the trunk and tail. While the tumor gives early symptoms at the beginning of the pancreas, Tumors located distally give symptoms very late, and physical examination findings appear only after spreading too much $(5-6)$. It was stated that the lesions in the head were mostly $5 \mathrm{~cm}$ in diameter, while of the lesions in the trunk and tail were mostly $10 \mathrm{~cm}$ in diameter (7). Also, pancreatic cancer has been identified to be more common at advanced ages (8). When the tumor is in the head part of the pancreas, it presses on the collector and patients most times apply to the clinic with the complaint of jaundice. Among the symptoms of pancreatic cancer exist with jaundice, abdominal pain, darkened urine, light-colored stool, weight loss, itching, slimming, and anorexia. In patients with pancreatic cancer has been reported that the risk increases in those who are fed with obesity, high-calorie diet, animal fats and red meat but the risk decreases in those who feed on fruits and vegetables (9).

Prolidase (Pro) (E.C.3.4.13.9) plays a role in the catabolism of proteins containing procollogen, collagen and proline or hydroxyproline in the cell. (10). In the work done have been reported that prolidase plays an important role in physiological and pathological processes such as embryonic development, wound healing, inflammation, carcinogenesis, angiogenesis, cell migration and cell differentiation (11 - 12). 
Adenosine deaminase (ADA) (E.C.3.5.4.4) is an enzyme that catalyzes hydrolytic deamination of adenosine to inosine and of deoxyadenosine to deoxycinosis. $(13-14)$. In the studies conducted, it has determined that ADA is very common in all tissues of mammals. The organs where ADA is found most respectively; cerebral cortex, liver, kidney, thymus, spleen and lymph nodules. It is stated that a large part of ADA is present in the cytoplasm of the cells and a small part in the nucleus. It has found that lymphocytes are 10 times more than erythrocytes $(15,16,17)$.

Glutathione reductase (GR) (E.C. 1.6.4.2) has an indirect but important task in terms of preventing oxidative damage in the cell by helping to maintain the amount of intracellular glutathione (GSH). Together with the glutathione peroxidase enzyme, glutathione is responsible for lowering the level of harmful hydrogen peroxide in the cell (18). Glutathione reductase inhibitors are applied in the treatment of cancer and malaria (19).

The glutathione s-transferase (GST) (E.C.2.5.1.18) enzyme has been found to be quite common in some organisms. Also GST enzyme different anti-cancer drugs such as chlorambusil, melphalan, cyclophosphamide and mitoxanthene, hormones, hydrocarbons and ethacrinic acid-like endogenous metabolites which diuretic drug, By adding it with GSH, it makes it more easily soluble in water and facilitates its excretion through urine and bile. Also, GST detoxifies harmful ends that occur in lipid and DNA in the presence of oxygen, the last metabolic products of DNA hydroperoxides, alkenol and endogenous electrophilic compounds (20).

The purpose of this study is is to determine the relationship between enzymatic antioxidants such as glutathione reductase (GR) and glutathione s-transferase (GST) and prolidase (PRO) and adenosine deaminase (ADA) in patients diagnosed with pancreatic cancer.

\section{METHODS}

This non-prospective study was performed according to the modified World Helsinki Declaration. After the receiving of the ethics committee of Van Regional Training and Research Hospital of Health Sciences University (S.B.Ü) dated 13 September 2018 and numbered 13, started to work. This study was done out in the Biochemistry laboratory of the Chemistry Department of the Faculty of Science of the University. The study population is formed from individuals in total of 20 patients with pancreatic cancer and 20 noncancerous healthy controls, changing ages between 4475 years, who were diagnosed and followed up in the Van Regional Training and Research Hospital of S.B.Ü. Biochemical parameters; determined with serum samples. Activities of PRO, ADA, GST and GR were determined from the serums separated by centrifugation of the blood samples taken from the patients included in the study.

\subsection{Taking samples}

Venous blood samples in accordance with the $3 \mathrm{ml}$ method taken from healthy and sick individuals selected as subjects in the study were centrifuged at $5000 \mathrm{rpm} /$ min for approximately 5 minutes and then the serums were separated. Serums were stored at -80 degree in until examined.

\subsection{Biochemical analysis}

\section{Determination of prolidase activity (PRO)}

Prolidase activity was performed according to the method of appointment proposed by Myara et al. (1982). Then absorbances were read at $515 \mathrm{~nm}$. (21)

\section{Determination of adenosine deaminase activity (ADA)}

Adenosine deaminase activity was performed according to the method of appointment proposed by Giustı [1974]. Absorbances of samples and sample blind tubes against pure water at $628 \mathrm{~nm}$ were read (22).

\section{Determination of glutathione reductase (GR) and glutathione-s-transferase (GST) activity activity}

Glutathione reductase activity was performed according to the method of appointment proposed by Goldberg and Spooner (1983). $100 \mu \mathrm{l}$ of pure water and $900 \mu \mathrm{l}$ of daily buffer were placed in the blind tube. $900 \mu$ of daily buffer and $100 \mu \mathrm{l}$ of serum were added to the sample tube and the tubes were vortexed. Tubes were incubated at $37^{\circ} \mathrm{C}$ for 10 minutes. Absorbances were read against the blind at $340 \mathrm{~nm}$ at 0 and 5 minutes (23).

Glutathione-s-transferase (GST) activity was performed according to the method of appointment proposed by Mannervik et al. (1981).

\subsection{Statistical Analysis}

The descriptive statistics for the features mentioned were expressed as mean and standard Deviation. T-Test was used in the comparison of binary groups providing the condition of normal distribution. On the other hand, the statistics of Mann Whitney $U$ test was used when the condition of normal distribution was not provided. Statistical significance level was taken as $p<0.05$ in calculations and SPSS statistical software was used for calculations.

\section{RESULTS}

Activities for GR, PRO, ADA and GST are showened in Table 1. When Table 1 is examined, the difference between patient and control group averages was found as statistically significant for GR, PRO, ADA and GST ( $p<0.05)$.

Average enzyme values for GR and GST are given in figure 1. When Figure 1 is examined, the average enzyme values for GR and GST in the patient group were found to be quite low compared to the control group $(p<0.05)$. 


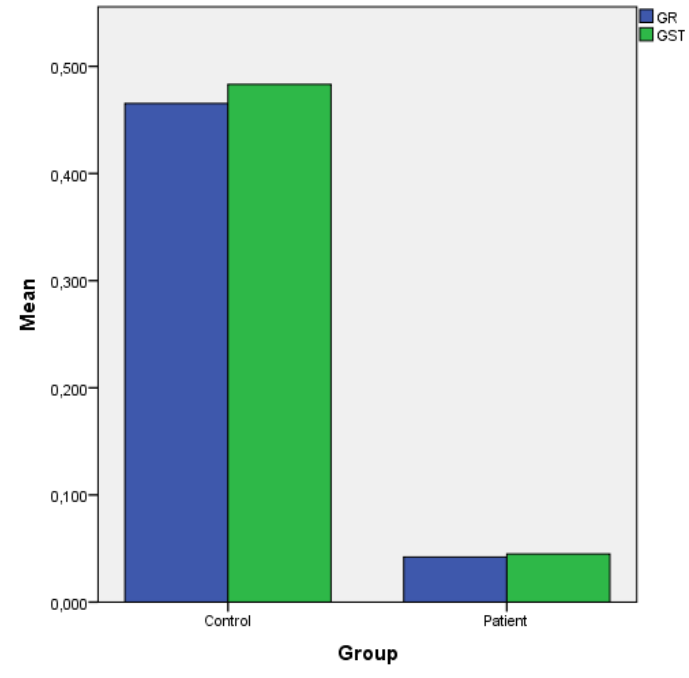

Figure 1. Average enzyme values for GR and GST in control and patient groups

Average enzyme values for prolidase and ADA are given in Figure 2. When Figure 2 is examined, the average enzyme values for Prolidase and ADA in the patient group were found to be significantly higher than the control group ( $<<0.05)$.

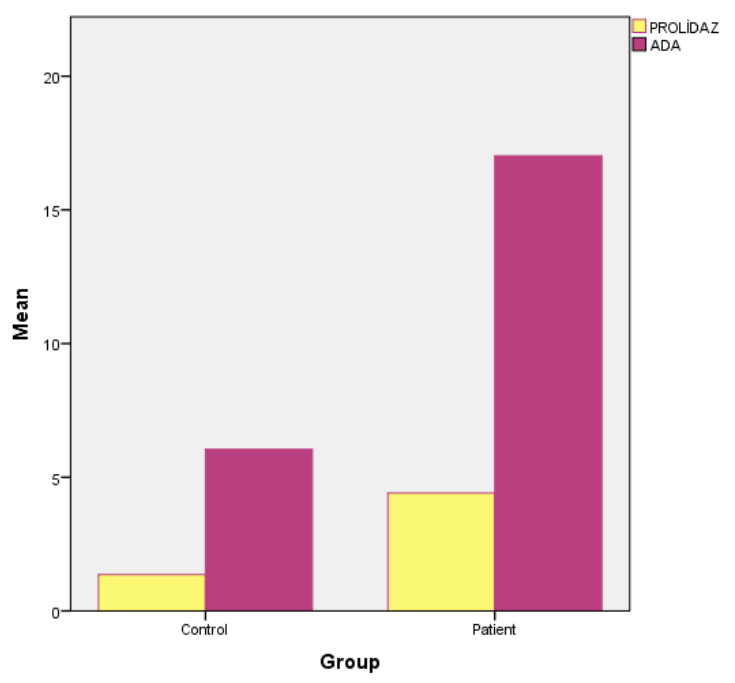

Figure 2. Average enzyme values for prolidase and ADA in control and patient groups

\section{DISCUSSION}

The high prevalence of pancreatic tumors, high level mortality, and surgical resection being still the only cure method make it important to know from the beginning the course of the disease without delay (25).

There are many studies examining the change of enzyme activities in cancerous cells or tissues. Made studies on ADA is the key enzyme of purine metabolism. Its general feature is to detach an amine from adenosine and convert it into inosine irreversibly. Many studies have been conducted on ADA enzyme in different types of cancer. ADA serum activity values were found to be particularly high in lymphoid tissues (26). When compared to normal people in the literature datas, It has been reported that an increase or decrease in activity occurs in cancer patients due to the new regulation of ADA enzyme. In one study, there was no change in the total activity of ADA in some types of cancer. In another study, it was found that DNAenzyme activity is of great importance in terms of reflecting the cancer cell's form of enzymatic change. This situation has been observed to attract the attention of researchers especially in terms of cancer-enzyme relationship $(27,28,29,30)$.In the literature studies conducted, ADA has found to be increased in tuberculosis (tbc) pleurisy, tbc pericarditis, tbc meningitis, malignancies, parapneumonic fluids and, in addition, collagen tissue disease related in pleural fluid samples (31,32). However, serum ADA studies are still limited.In literature datas, serum ADA activity has been reported to increase in typoid fever, infectious mononucleosis, liver diseases, acute leukemia, brucellosis, pneumonia, rheumatoid arthritis and malignancies $(33,34)$. Change of ADA activity in cancer cells or tissues, In addition to understanding this metabolism, it has been stated that it can assist the clinician in diagnosing the disease, following the treatment or evaluating the prognosis. Total ADA enzyme levels; high performance liquid chromatography can be determined by enzymatic or colorimetric methods. The measurement of ammonia released by the conversion of adenosine to inosine is one of the simplest methods (35). In this study, serum ADA activity was found to be significantly higher in patient group levels than in the healthy control group $(p<0.05)$ (Table1). However, serum ADA studies are still limited.

Table 1. Descriptive statistics and Comparison results

\begin{tabular}{lllll}
\hline & Group & $n$ & Mean \pm Std. Deviation & $p$ \\
\hline GR ( U/L) & Control & 20 & $0.465 \pm 0.112$ & 0.001 \\
& Patient & 20 & $0.042 \pm 0.020$ & \\
PRO (U/L) & Control & 20 & $1.356 \pm 0.203$ & 0.001 \\
& Patient & 20 & $4.409 \pm 0.722$ & \\
ADA ( U/L) & Control & 20 & $6.043 \pm 0.135$ & 0.001 \\
& Patient & 20 & $17.023 \pm 5.390$ & \\
GST (U/L) & Control & 20 & $0.483 \pm 0.051$ & \multirow{2}{*}{0.001} \\
& Patient & 20 & $0.045 \pm 0.032$ & \\
\hline
\end{tabular}

As a result in this study, the high ADA activity in the patient group can be considered as a factor that increases the risk of cancer.

GR is a dimer composed of 2 subunits that convert oxidized glutathione into reduced form. Each subunit contains 3 structural areas: NADPH binding area, FAD binding area and interface area. Electrons are often transferred from NADPH to FAD during the reduction reaction of glutathione. It is then transferred to the oxidized glutathione by transferring it to the disulfide bridge between the two cysteines in the subunits. It is then transferred to the oxidized glutathione by transferring it to the disulfide bridge between the two cysteines in the subunits. More studies are needed to determine whether it is useful in preventing or treating GR pancreatic cancer (36). GR is the homodimeric enzyme which on duty involved in the regeneration of glutathione. It is also 
important in selenium metabolism (37). In a study conducted by Navarro et al. when mice born with tumors were compared with the control group, there was no significant difference in GR enzyme activity (38). In the study conducted by Tisdale et al., GR activities were found to be high in patients with solid tumors (39). By Yavuz et al. In the study performed which on patients with skin cancer, GR activity was found to be low in accordance with the literature (40). In the another study done, it was found that glutathione reductase activity decreased in diabetes (41). In our study, serum GR activity patient group levels were lower than the healthy control group $(p<0.05)$ (Table 1$)$. Consequently, low GR activity in the blood in this study can be considered as a factor that increases the risk of cancer.

GST is an antioxidant which molecular weights are 20,00025,000 dalton and each subunit consists of 200-240 amino acids. It is applied for the first time by Boyland et al in the rat liver (42). The GST enzyme catalyzes the conjugation of glutathione with toxic metabolites, leading to detoxification of toxic metabolites. GST plays an important role in antioxidant defense system and protective system which is in the fight against many diseases in humans (43). In the study done, it was found that antioxidant GST activities were lower in liver cancer patients compared to control patients (44). In the another study done, antioxidant enzyme activities such as GST were found low in cancer patients (45). In a study conducted by Turan et al., GST activity was found to be low in patients with abortion compared to healthy control groups (46). In our study found that serum GST activity patient group levels were lower than the healthy control group (Figure 1). Consequently, low of GST activity in the blood in this study can be considered as a factor that increases the risk of cancer.

PROis a hydrolase specific to dipeptides with proline (pro) or hydroxyproline (Hyp) at the C terminal. This enzyme plays an important role in collagen and procollogen destruction because it contains abundant (25\% Pro and Hyp) in the structure of the collagen (47). Proline takes place in the central nervous system in general (48). In this study, serum pro activity patient group levels were higher than the healthy control group ( $p<0.05$ ) (Table 1 ). High prolidase activity in the blood can be considered as a factor that increases the risk of cancer.

\section{CONCLUSION}

As a result, prolidase, adenosine deaminase, glutathione reductase and glutathione s-transferase enzyme activities may play an important role in the etiopathogenesis of pancreatic cancer.

In this study we have done, ADA, GR, GST and Prolidase enzyme activities were measured for the first time in pancreatic cancer. Therefore, we believe that it will make an important contribution to the literature.
* This study was presented as abstract at the International Medical and Health Sciences Research Congress (UTSAK) held at Bandırma University on 11-14 July 2019. page:93

\section{REFERENCES}

[1] Mills SE. Sternberg's Diagnostic surgical pathology. Lippincott Williams \& Wilkins. 2010; 2: 1442-1443.

[2] Abeloff MD, Armitage JO, Niederhuber JE. Carcinoma of the Pancreas. Clin Oncol. 2008;4 thed. Philadelphia p. 1596.

[3] Wilkowski R, Boeck S, Ostermaier S. Chemoradiotherapy with concurrent gemcitabine and cisplatin with or without sequential chemotherapy with gemcitabine - cisplatin vs chemoradiotherapy with concurrent 5 -fluorouracil in patients with locally advanced pancreatic cancer - a multi-centre randomised phase II study. Br J Cancer 2009;101: 1853-59.

[4] Jemal A, Siegel R, Ward E. Cancer statistics. CA Cancer J Clin. 2008;58 (2): $71-96$.

[5] Bell ET. Carcinoma of the pancreas, 1.A clinical and pathologic study of 609 necropsied cases, 11. The relation of carcinoma of the pancreas to diabetes mellitus.1957; Am J Pathol 33 499.

[6] Nakase A, Watsumoto Y, Uchida K.Surgical treatment of cancer of the pancreas and the periampullary region; cumulative results in 57 institutions in Japan. Ann Surg 1977;185: 52.

[7] Cubilla A.X , Fitzgeral P.J. Duct cell adenocarcinoma.In Sommers S.C., Rosen PJP. (eds.): Pankreas Cancer: Pathology Annual. 1978; Part 1, P. 241. New York, Appelton - CenturyCrofts.

[8] Greer JB, Yazer M, Raval J. Significant association between $\mathrm{ABO}$ blood group and pancreatic cancer. World J Gastroenterol 2010;16[44]: 5588-5591.

[9] Hart AR. Pancreatic cancer: any prospects for prevention? Postgraduate Medical Journal. 1999;75[887]:521-526.

[10] Zanaboni G, Dyne KM, Rossi A, Monafo V, Cetta G. Prolidase deficiency: biochemical study of erythrocyte and skin fibroblast prolidase activity in Italian patients. Haematologica 1994;79:13-18.

[11] Palka JA, Phang JM. Prolidase activity in fibroblasts is regulated by interaction of extracellular matrix with cell surface integrin receptors, J Cell Biochem.1997;67: 166-175.

[12] McRae PA, Porter BE. The perineuronal net component of the extracellular matrix in plasticity and epilepsy. Neurochem Int 2012;61: 963-972.

[13] Lizuka H, Kouzumi H, Kamigaki K, Aoyagi T, Miura Y. Two forms of adenosine deaminase in pig epidermis. J.Dermatol 1981;8: 91-95.

[14] Oosthizen HM, Ungerer J.P, Bissbort S.H. Kinetic determination of serum adenosine deaminase. Clinical Chemistry.1993; 39 (10): 2182-2185.

[15] Dissing J, Kaudsen B.Adenosine deaminase deficiency and combined immunodeficiency syndrome. Lancet 1972;2: 1316.

[16] Baganha MF, Pego A, Lima M.A, Gaspar E.U, Pharma B. Serum anf plevral edenosine deaminase correlation with lymphocytic populations. Chest, 1990;97: 605-610.

[17] Chotfiner EG, Cloft HJ, Tartaglia AP, Mitchell S.B. Elevated adenosine deaminase activity and hereditary hemolytic anemia J Clin Invest 1987;79:1001-1005.

[18] Meister A. The Glutathione-Ascorbic Acid Antioxidant Systems in An J Biol Chem 1994; 269: 9397-9400. 
[19] Şenturk M, Talaz O, Cavdar H, Ekinci D, Kufrevioglu OI. Yeni sentezlenen bazı organik nitratların glutatyon redüktaz enzim kinetiği üzerine etkilerinin incelenmesi. Bioorganic \& Medicinal Chemistry Letters.2009;19: 3661-3663.

[20] Arıas I.M, Jacoby W.B. Glutathione: Metabolism and Function. Kroc. Found. Series.1976;6,335.

[21] Myara I, Charpentier C, Lemonnier A. Optimal conditions for prolidase assay by proline colorimetric determination: application to iminodipeptiduria. Clin. Chim. Acta.1982; 125: 193- 205.

[22] Giustı G. Adenosinedeaminase. In: HV BergmeyerandWeinheim [eds]. Methods of Enzymatic Analysis. Deerfield Beach, Fl: VerlagChemmie.1974;1092 - 99.

[23] Goldberg DM, Spooner R.J. Methods of enzymatic analysis. Bergmeyer HV.1983; 3: 258-265.

[24] Mannervik B, Guthenberg C. Glutathionetransferase (human plasenta). Meth.Enzymol 1981; 77: 231-235.

[25] Abeloff MD, Armitage JO, Niederhuber JE. Carcinoma of the Pancreas. Clinical Oncology.2 008;4 thed. Philadelphia p. 1596.

[26] Wilson DK, Rudolph FB, Quiocho FA. Atomic Structure of Adenosine Deaminase Complexed with TransitionState Analge: Understanding Catalysis and Imunodefiency Mutations. Science 1991; 252: 1278-1284.

[27] Durak I, Işık ACÜ, Canbolat O, Akyol Ö, Kavutçu M. Durak I, Işik AC, Canbolat O, Akyol O, Kavutçu M. Adenosine deaminase, 5 ' nucleotidase, xanthine oxidase, superoxide dismutase, and catalase activities in cancerous and noncancerous human laryngeal tissues. Free Radic Biol Med 1993, 15;681-684.

[28] Durak I, Çetin R, Canbolat O, Çetin D, Yurtaslanı Z, Ünal A. Adenosine deaminase, 5'nucleotidase guanase and cytidine deaminase in gastric tissues from patients with gastric cancer. Cancer Lett.1994;15;84(2):199-202.

[29] Akyol Ö, Arslanoğlu R, Durak İ. Avtivities of free radical and DNA turn-over enzymes in cancerous and non-cancerous brain tissues. Redox Report.1995;1,255-259.

[30] Canbolat O, Durak I, Çetin R, Kavutçu M, Demirci S, Öztürk S. Activities of adenosine deaminase, 5'nucleotidase,guanase and cytidine deaminase enzymes in cancerous and non,cancerous human breast tissues. Breast Cancer Research and Treatment.1996; 37: 189-193.

[31] Segura RM, Pascual C, Ocana I. Adenosine deaminase in body fluid: A useful diagnostic tool in tuberculosis. Clin Biochem 1989; 22: 141-148.

[32] Light R.W. Clinical manifestations and useful tests. In: Light RW [ed]. Pleural Diseases. Baltimore: Williams \&Wilkins.1995;95[8]: 36-74.

[33] Koehler LH, Benz E.J. Serum adenosine deaminase methodology and clinical applications. Clin Chem 1962;8: 13340.
[34] Nishikawa H, Suga M, Ando M. Serum adenosine deaminase activity with Mycoplasma pneumoniae. Chest. 1988; 94: 1315.

[35] Aghaei M, Karami F, Salami S, Atri M. Diagnostic Value of Adenosine Deaminase Activity in Benign and Malignant Breast Tumors. Clin Bichem 2005;38(10):887-891.

[36] Memişoğulları R. Diyabette Serbest Radikallerin Rolü ve Antioksidanların Etkisi. Düzce Tıp Fakültesi Dergisi.2005; 3: 30-39.

[37] Björkhem-Bergman L, Jönsson K, Eriksson LC, Olsson J.M, Lehmann S, Paul C, Björnstedt M. Drug-resistant human lung cancer cells are more sensitive to selenium cytotoxicity :Effects on thioredoxin reductase and glutathione reductase. Biochem Pharmacol. 2002;63[10]:1875-84.

[38] Navarro J, Obrador E, Carretero J, Petschen I, Aviñó J, Perez P, Estrela JM. Changes in glutathione status and the antioxidant system in blood and in cancer cells associate with tumour growth in vivo. Free Radic Biol Med. 1999;26(3-4):410-8.

[39] Tisdale MJ, Mahmoud M.B.Activities of free radicalmetabolizing enzymes in tumours. Br J Cancer. 1983;Jun;47[6]:809-12.

[40] Yavuz I.H, Özaydin Yavuz G, Güneş Bilgili S, Demir H, Demir C. Deri kanseri hastalarının serum oksidatif stres parametrelerinin değerlendirilmesi. Bozok Tıp Dergisi.2018; 8(3): 127-133. (Turkish)

[41] Memişoğulları R. Diyabette Serbest Radikallerin Rolü ve Antioksidanların Etkisi. Düzce Tıp Fakültesi Dergisi.2005; 3: 3039. (Turkish)

[42] Hayes J.D, Flanagan J.U, Jowsey I.R. Glutathione transferases. Annual Review of Pharmacology and Toxicology.2005; 45: 51-88.

[43] Knapena MF, Zusterzeel PL, Peters W.H, Steegers E.A. Glutathione and glutathi-one-related enzymes in reproduction. A review. Eur J Obstet Gynecol Reprod Biol. 1999;82: 171-84.

[44] Lin CC, Yin MC. B Vitamins Deficiency and Decreased AntiOxidative State in Patients with Liver Cancer. Eur J Nutr, 2007; 46(5): 293-9.

[45] Gonzales R,Auclair C, Voisin E, Gautero H, Dhermy D, Boivin P. Superoxide dismutase, catalase, and glutathione peroxidase in red blood cells from patients with malignant diseases. Cancer Res. 1984; 44(9): 4137 - 9.

[46] Turan K, Uçkan K, Sarıkaya E, Demir H, Demir C. Investigation of prolidase, adenosine deaminase, glutatatione s-transferase and glutatione reductase activites in patients with abortus Imminens. J Clin Anal Med. 2017; 8(10): 519-522.

[47] Öner I.Y, Gürdöl F, Öner P. Serup prolidaz I aktivitesinin kemik yapım - yıkım indeksi olarak değerlendirilmesi. İst Tıp Fak Mecmuası.1999; 62: 301-306. (Turkish)

[48] Hauptmann, M, Wilson D.F, Erecinska M. High affinity proline uptake in rat brain synaptosomes. FEBS Lett. 1983;161: 301305. 